\title{
Relationship between male moths of Cryptoblabes gnidiella (Millière) (Lepidoptera: Pyralidae) caught in sex pheromone traps and cumulative degree-days in vineyards in southern Uruguay
}

María Valeria Vidart', María Valentina Mujica, María Victoria Calvo ${ }^{1}$, Felicia Duarte', Carlos María Bentancourt ${ }^{1}$, Jorge Franco ${ }^{2}$ and Iris Beatriz Scatoni ${ }^{1^{*}}$

\begin{abstract}
Cryptoblabes gnidiella (Millière) (Lepidoptera: Pyralidae) has been known in Uruguay for 30 years and only in vineyards, despite being polyphagous. In recent years, this pest has caused sporadic but serious damage on some grapevine cultivars. Understanding the insect's phenology and developing a monitoring program are essential aspects of integrated pest management. We monitored males using sexual pheromone traps on four cultivars of vine, Pinot noir, Tannat, Gewürztraminer, and Cabernet Sauvignon, in two vine-growing establishments in the Department of Canelones and compiled data on the accumulated effective temperatures for the southern area of Uruguay. We determined that this species undergoes three generations per year and overwinters without diapause as larvae on dried grapes remaining after harvest. Using the proportion of cumulative male moths caught from December to May from 2003-2007 on the four cultivars and the sum of effective temperatures above two previously-published lower-threshold temperatures for development, $12.26^{\circ} \mathrm{C}$ and $13^{\circ} \mathrm{C}$, statistically significant logistic models were estimated. Predictions based on the resulting models suggested that they would be acceptable tools to improve the efficiency of integrated management of this pest in Uruguay.
\end{abstract}

Keywords: Honeydew moth, Flight activity, Hibernation, Degree-day models

\section{Background}

In Uruguay, vineyards have undergone sustained plant replacement. In the past 20 years, most of the country's 8,000 hectares of vineyards have been replaced by newer, healthier, and higher-quality grapevine cultivars. Eightynine percent of the wine growing area is concentrated in southern Uruguay, especially in Canelones Department (MGAP-DIEA 2011). Unlike in other wine-producing areas of the world, pests have been a minor problem in Uruguay's vineyards, eliminating the need for widespread applications of insecticides (Bentancourt and Scatoni 1999).

Cryptoblabes gnidiella (Millière) (Lepidoptera: Pyralidae) has become a sporadic pest in Uruguay capable of causing

\footnotetext{
* Correspondence: iscatoni@fagro.edu.uy

'Department of Plant Protection, Faculty of Agronomy, University of the

Republic, Ave. E. Garzón 780, Montevideo 12900, Uruguay

Full list of author information is available at the end of the article
}

significant damage to some grapevine cultivars in certain years and areas (Bentancourt and Scatoni 2006). This polyphagous moth, is native to the Mediterranean regions of Europe and reported from Africa, Asia, New Zealand, North and South America (Bagnoli and Lucchi 2001, Ioriatti et al. 2012). It has been known in Uruguay for 30 years, but only reported from vineyards (Scatoni and Bentancourt 1983). Since its appearance, it has displaced in importance two other grape pests: Argyrotaenia sphaleropa (Meyrick) and Bonagota salubricola (Meyrick) (Lepidoptera: Tortricidae). The larvae feed on grape cluster, especially at the end of season when the fruits are already mature. Feeding damage produces conditions conducive to the development of rots. The economic losses become more significant when harvest is delayed, due to an increase in population and a potential additional generation. Also, rainfall and high humidity create conditions suitable for rots 
causing further deterioration of the clusters (Bentancourt and Scatoni 2006).

Knowing pest phenology is an essential aspect of developing a management program. The identification of the sex pheromone of C. gnidiella provided a monitoring tool for adults now widely used (Bjostad et al. 1981, Anshelevich et al. 1993). Monitoring of adults as well as degree-days (DD) allows the prediction of pest phenological events for management purposes. Numerous reports have correlated species catches with DD for several species of Lepidoptera; as an example, these relationship have been studied for Lobesia botrana (Lepidoptera: Tortricidae), the main vineyard pest in Europe (Del Tio et al. 2001, Milonas et al. 2001). The thermal constant and lower thresholds of development for $C$. gnidiella were determined by Avidov and Gothilf (1960) for Israel and by Ringenberg et al. (2005) for Brazil. There is, however, no information available about the relationship between DD and catch levels.

Understanding a pest's phenology and monitoring its populations are essential aspects of integrated pest management. The objective of this research was to better understand the phenology of this insect in Uruguay and the damage it inflicts on cultivars with different maturity dates to develop a forecasting system that uses pheromone traps and the accumulation of effective temperatures. For these purposes, population's growth models were run for each cultivar and for all cultivars.

\section{Materials and methods}

\section{Study sites}

The study was carried out in two vineyards, $10 \mathrm{~km}$ apart, in Canelones Department, which represents our country's wine production. One was located in Juanicó (34.58'S, $\left.56^{\circ} 25^{\prime} \mathrm{W}\right)$ and the other in Progreso $\left(34^{\circ} 68^{\prime} \mathrm{S}, 56^{\circ} 21^{\prime} \mathrm{W}\right)$. The first being a 200 hectares vineyard and the second 50 hectares. Both vineyards have several cultivars with varying harvest dates, ranging from mid-February to mid-April. Vineyard design is presented in Table 1 . The vineyard was managed without irrigation and in all cases with resident inter-row vegetation and herbicides along the row. In

Table 1 Vineyard design at Progreso and Juanicó, Uruguay

\begin{tabular}{|c|c|c|c|c|c|}
\hline Site & Cultivar & Rootstock & $\begin{array}{c}\text { Year } \\
\text { planted }\end{array}$ & $\begin{array}{l}\text { Planting } \\
\text { distance } \\
\text { (m) }\end{array}$ & $\begin{array}{l}\text { Conductior } \\
\text { system }\end{array}$ \\
\hline \multirow[t]{2}{*}{ Progreso } & $\begin{array}{l}\text { Cabernet } \\
\text { Sauvignon }\end{array}$ & $\mathrm{SO} 4$ & 1986 & $\begin{array}{c}3.00 \times \\
1.00\end{array}$ & lyre \\
\hline & Pinot noire & $\mathrm{SO} 4$ & 1994 & $\begin{array}{c}3.00 \times \\
1.25\end{array}$ & lyre \\
\hline \multirow[t]{2}{*}{ Juanicó } & Tannat & $\mathrm{SO} 4$ & 1994 & $\begin{array}{c}3.00 \times \\
1.25\end{array}$ & lyre \\
\hline & Gewürztraminer & $\mathrm{SO} 4$ & 1986 & $\begin{array}{c}3.00 \times \\
1.00\end{array}$ & lyre \\
\hline
\end{tabular}

neither vineyard were insecticides applied during the study period, from 2003-2007.

\section{Monitoring adults}

Adult populations were monitored with delta traps baited with $1 \mathrm{mg}$ of synthetic sex pheromone (Z11-16: Ald and Z13-18: Ald, 1:1, Yogev Ltd, Rishon Le'zion, Israel). Traps were placed $1.5 \mathrm{~m}$ above the ground and checked weekly. In Juanicó, three traps were placed $200 \mathrm{~m}$ apart on Pinot noir, Tannat, and Gewürztraminer cultivars and were monitored from December 2003 to June 2007. In Progreso, one trap was placed on Cabernet Sauvignon from October 2004 to June 2007. Each cultivar occupied an area of about one hectare and the trap was placed in the middle of the plot. Pheromone lures were replaced weekly and sticky bottom whenever necessary.

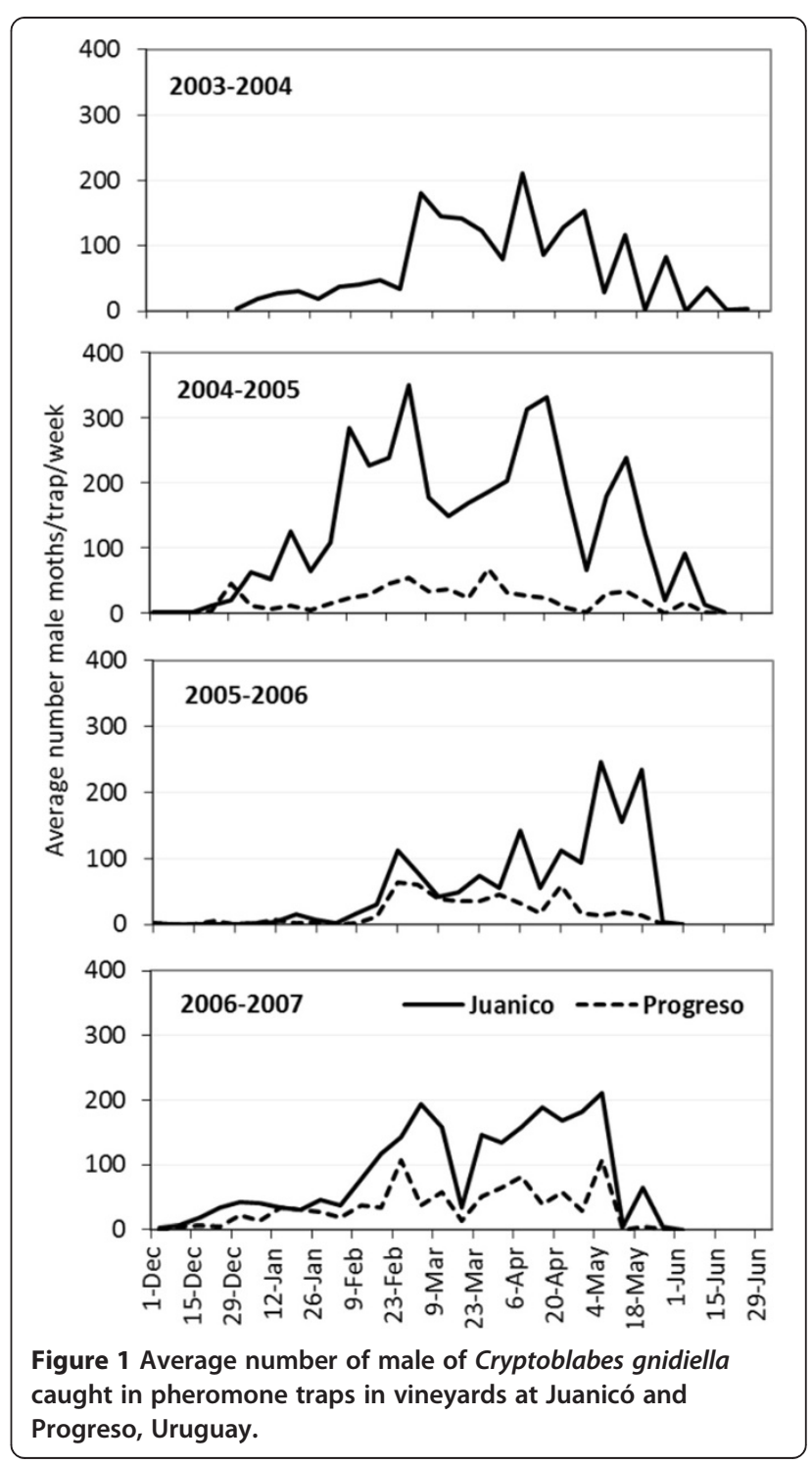


Table 2 Degree-days accumulated by generation of Cryptoblabes gnidiella in Uruguay from 2003-2007

\begin{tabular}{|c|c|c|c|c|c|c|}
\hline Year & $\begin{array}{c}\text { Start date }{ }^{1} \\
1^{\text {st }} \text { generation }\end{array}$ & $\begin{array}{c}\text { DD accumulated } \\
\text { LTT } 13^{\circ} \mathrm{C}^{2}\end{array}$ & $\begin{array}{c}\text { DD accumulated } \\
\text { LTT } 12.26^{\circ} \mathrm{C}^{3}\end{array}$ & $\begin{array}{c}\text { Start date }{ }^{1} \\
2^{\text {nd }} \text { generation }\end{array}$ & $\begin{array}{c}\text { DD accumulated } \\
\text { LTT } 13^{\circ} \mathrm{C}^{2}\end{array}$ & $\begin{array}{l}\text { DD accumulated } \\
\text { LTT } 12.26^{\circ} \mathrm{C}^{3}\end{array}$ \\
\hline 2004 & 29-Jan & 482 & 527 & 01-Apr & 999 & 1090 \\
\hline 2005 & 27-Jan & 527 & 570 & 31-Mar & 1009 & 1098 \\
\hline 2006 & 02-Feb & 489 & 536 & 13-Apr & 989 & 1089 \\
\hline 2007 & 22-Jan & 500 & 540 & 19-Mar & 1011 & 1092 \\
\hline Mean & & $500 \pm 20$ & $543 \pm 19$ & & $1002 \pm 10$ & $1092 \pm 04$ \\
\hline
\end{tabular}

${ }^{1}$ Start date of each generation was determined from catches of males in pheromone traps, ${ }^{2}$ lower-temperature thresholds determined by Avidov and Gothilf (1960), ${ }^{3}$ lower-temperature thresholds determined by Ringenberg et al. (2005).

\section{Monitoring larvae}

Larvae were monitored from December until leaf fall. For each of the cultivars where adult traps were placed, 90 clusters (two per vine) were collected at random every 2 weeks. In the laboratory, we recorded the presence of damage and the number of larvae and pupae per cluster. Insects collected were stored in boxes with the clusters and kept until either adults or parasitoids emerged. To understand the behavior of the overwintering larvae, after harvest we collected 60 infested clusters per year from each cultivar and stored them in $25 \times 30 \mathrm{~cm}$ netting cloth bags in the laboratory for $24 \mathrm{~h}$. The bags were returned to the vineyard the following day and hung from the wires of the lyre. Bags were checked every fortnight to verify larval development and adult emergence per cultivar. In addition, during the plants' dormancy period we directly observed beneath the rhytidome and in other places where the larvae might be (leaf litter, dead leaves).

\section{Phenological models}

Daily maximum and minimum temperatures were taken from the Experimental Station of National Agricultural Research Institute Las Brujas from 2003-2007. This station is located 10 and $12 \mathrm{~km}$, respectively, from the Progreso and

Table 3 Average number of male moths of Cryptoblabes gnidiella caught in pheromone traps at two sites in Uruguay

\begin{tabular}{|c|c|c|c|c|c|c|}
\hline \multirow{3}{*}{$\begin{array}{c}\text { Site } \\
\text { Juanico }\end{array}$} & \multirow{3}{*}{$\begin{array}{c}\text { Grapevine } \\
\text { cultivar }\end{array}$} & \multicolumn{5}{|c|}{$\begin{array}{l}\text { Average number of male moths/trap/ } \\
\text { week }^{1}\end{array}$} \\
\hline & & $\begin{array}{c}2003- \\
2004\end{array}$ & \multicolumn{2}{|c|}{$\begin{array}{c}2004- \\
2005\end{array}$} & $\begin{array}{c}2005- \\
2006\end{array}$ & $\begin{array}{c}2006- \\
2007\end{array}$ \\
\hline & & 55.9 cde & 103.7 & $a b$ & 33.0 efg & 42.5 def \\
\hline Juanico & Tannat & 58.0 cde & 92.7 & $a b c$ & 34.3 efg & $70.7 \mathrm{bcd}$ \\
\hline Juanico & Gewürztraminer & 60.5 bcde & 118.0 & $\mathrm{a}$ & 57.1 cde & $72.2 \mathrm{bcd}$ \\
\hline Progreso & $\begin{array}{l}\text { Cabernet } \\
\text { Sauvignon }\end{array}$ & - & 15.8 & g & 13.0 & $23.9 \mathrm{fg}$ \\
\hline Mean $^{2}$ & & & 61.6 & $a$ & $28.7 \quad c$ & $45.2 \quad \boldsymbol{b}$ \\
\hline
\end{tabular}

Juanicó vineyards. Degree-days were estimated using the Baskerville and Emin (1969) method based on maximum and minimum air temperature.

To estimate the mean generation time under field conditions, we used the cumulative sum of effective temperatures (DD) between the start of one generation's flight and the next. The beginning of the overwintering flight was taken as the first date on which male moths were caught on consecutive days; this occurred in early December in all 4 years of the study. For this reason we used December $1^{\text {st }}$ as the biofix. A similar method was used to set the biofix of Cydia pomonella (Riedl et al. 1976) and other Tortricidae (Knight and Croft 1991). To set the start of subsequent generations, we used the dates on which number of male moths caught were high after periods of consistently declining or zero catches. According to Avidov and Gothilf (1960), C. gnidiella requires a minimum temperature of $13^{\circ} \mathrm{C}$ for development and $500 \mathrm{DD}$ to complete a generation. However, Ringenberg et al. (2005) suggest a lower threshold of development of $12.26^{\circ} \mathrm{C}$ and 570 DD to complete a generation.

Mathematical models were adjusted using the accumulation of DD and the proportion of cumulative catches at the two sites for the 4 years and four grapevine cultivars. These models can be used to predict how the population will develop as a function of DD accumulated over time. We used one logistic model: $\operatorname{logit}(p)=a+b x$; where logit $(p)=\log$

Table 4 Percentage of clusters damaged by Cryptoblabes gnidiella on different grapevine cultivars in Uruguay at harvest time

\begin{tabular}{|c|c|c|c|c|c|c|}
\hline \multirow{2}{*}{ Site } & \multirow{2}{*}{ Grapevine cultivar } & \multicolumn{4}{|c|}{ Percent cluster damage } & \multirow{2}{*}{$\begin{array}{c}\text { Harvest } \\
\text { dates }\end{array}$} \\
\hline & & 2004 & 2005 & 2006 & 2007 & \\
\hline Juanicó & Pinot noir & 0 & 0 & 0 & 0 & $\begin{array}{l}\text { 29-Jan to } \\
\text { 5-Feb }\end{array}$ \\
\hline Juanicó & Tannat & 6 & 10 & 5 & 4 & $\begin{array}{c}5 \text { to } \\
\text { 15-March }\end{array}$ \\
\hline Juanicó & Gewürztraminer & 81 & 83 & 50 & 63 & $\begin{array}{c}5 \text { to } \\
\text { 19-March }\end{array}$ \\
\hline Progreso & Cabernet Sauvignon & - & 0 & 8 & 6 & $\begin{array}{c}12 \text { to } \\
\text { 20-March }\end{array}$ \\
\hline
\end{tabular}


Table 5 Logistic models estimated for each grapevine cultivar and for all cultivars in a joint model

\begin{tabular}{|c|c|c|c|c|c|c|c|c|c|c|}
\hline \multirow{3}{*}{$\begin{array}{l}\text { Grapevine } \\
\text { cultivar }\end{array}$} & \multicolumn{5}{|c|}{ LTT $13^{\circ} \mathrm{C}^{1}$} & \multicolumn{5}{|c|}{ LTT $12.26^{\circ} \mathrm{C}^{2}$} \\
\hline & \multirow{2}{*}{$a$} & \multirow{2}{*}{$b$} & \multicolumn{3}{|c|}{ 95\% Confidence limits } & \multirow{2}{*}{$a$} & \multirow{2}{*}{$b$} & \multicolumn{3}{|c|}{ 95\% Confidence limits } \\
\hline & & & LL & UL & & & & LL & UL & \\
\hline Pinot noir & -5.8436 & 0.0063 & 0.0038 & 0.0088 & at & -6.1673 & 0.0059 & 0.0036 & 0.0083 & $\mathrm{a}$ \\
\hline Tannat & -7.4594 & 0.0080 & 0.0047 & 0.0112 & $\mathrm{a}$ & -7.9213 & 0.0076 & 0.0045 & 0.0107 & $\mathrm{a}$ \\
\hline Gewürztraminer & -6.1224 & 0.0068 & 0.0040 & 0.0095 & a & -6.4848 & 0.0064 & 0.0038 & 0.0090 & a \\
\hline C. Sauvignon & -5.5514 & 0.0066 & 0.0037 & 0.0095 & $a$ & -5.9016 & 0.0062 & 0.0035 & 0.0090 & a \\
\hline Joint model & -6.1559 & 0.0068 & 0.0054 & 0.0082 & & -6.5190 & 0.0064 & 0.0051 & 0.0078 & \\
\hline
\end{tabular}

The models relate the proportion of cumulative catches in pheromone traps to the accumulated degree-days in each year using the lower-temperature thresholds (LTT) ${ }^{1}$ determined by Avidov and Gothilf (1960) ${ }^{2}$ determined by Ringenberg et al. (2005), LL, confidence lower limit, UL, confidence upper limit $\boldsymbol{a}$ and $\boldsymbol{b}$ parameters estimated for the logistic models, logit $(\hat{p})=a+b \cdot D D p=\frac{e^{(a+b . D D)}}{\left(1+e^{(a+b . D D)}\right)}$.

†: Same letter indicates non-significant differences between $\boldsymbol{b}$ values $(p \leq 0.05)$ for the different grapevine cultivars.

$(p /(1-p)), p$ is the cumulative proportion of adult males associated with $x, a$ and $b$ are parameters of the model, and $x$ is the cumulative DD. Estimation was done in the framework of generalized linear models (McCullagh and Nelder 1999) assuming a binomial distribution and a logit link function. To test the hypotheses of equality of the model parameters, we compared confidence limits, (when two intervals overlapped, the parameters were considered to be equal; otherwise they were defined as different). Finally, to compare the averages of weekly catches, we applied likelihood ratio and Tukey-Kramer tests. These comparisons of mean values were made in framework of the generalized linear model (McCullagh and Nelder 1999). Analyses were done using the GLIMMIX procedure in SAS v. 9.2 (SAS Institute Inc 2009).

\section{Results}

\section{Monitoring adults}

Changes in the C. gnidiella populations in vineyards based on adult monitoring with pheromone traps from 20032007 are presented in Figure 1. Adults that fly in early December belong to the overwintering generation, which lasts until late January-early February. The first generation develops during February and March, the second and final generation develops primarily after harvest and the females lay eggs in remaining clusters.

Thermal requirements starting from biofix (December $\left.1^{\text {st }}\right)$ also identified three generations. We use $13^{\circ}$ and $12.26^{\circ} \mathrm{C}$ as lower-threshold temperatures and 500 and 570 $\mathrm{DD}$, respectively, as thermal constants. Table 2 shows the starting dates and accumulated DD of the first and second generations in different years, using the temperature thresholds above mentioned.

In Juanicó, number of male moths caught in traps was always higher than in Progreso, and there was also a year effect, as indicated by the higher 2004-2005 catches for all cultivars in Juanicó (Table 3). However, no differences were found among cultivars within a growing season at this site.
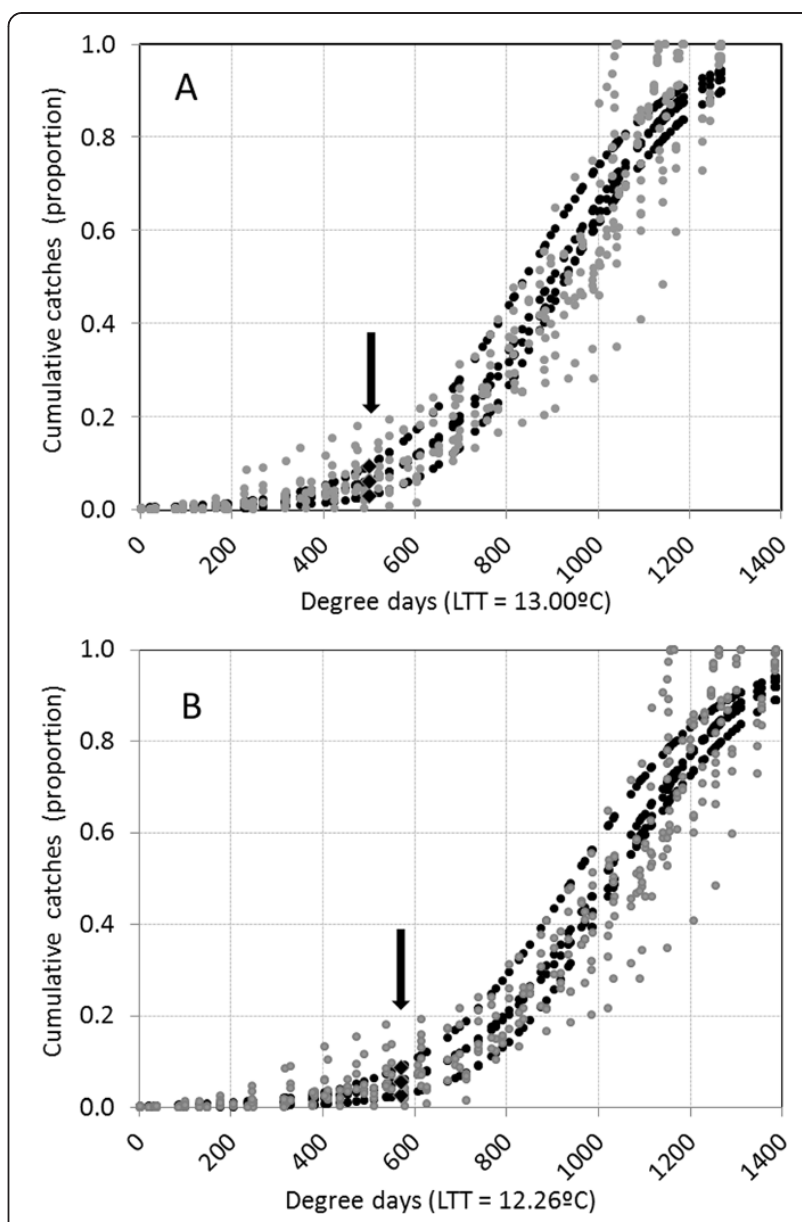

Figure 2 Relationship between degree-days and the cumulative proportion of adult males of Cryptoblabes gnidiella caught in pheromone traps on each of four grapevine cultivars between $1^{\text {st }}$ December and $31^{\text {st }}$ May in 4 years and at two sites in Uruguay. A) Employs the lower-temperature threshold determined by Avidov and Gothilf (1960); B) uses the lower-temperature threshold estimated by Ringenberg et al. (2005). Observed values are grey, estimated values are black, and estimated proportions at the end of the first generation are identified with an arrow. 
Table 6 Estimated proportions of cumulative catches for the average DD values of the logistic curve for four grapevine cultivars in Uruguay and at the end of the first generation in the joint model

\begin{tabular}{|c|c|c|c|c|c|c|c|}
\hline \multirow{4}{*}{$\begin{array}{l}\text { Models for } \\
\text { each cultivar }\end{array}$} & \multicolumn{4}{|c|}{$\operatorname{LTT} 13^{\circ} \mathrm{C}^{1}$} & \multicolumn{3}{|c|}{ LTT $12.26^{\circ} \mathrm{C}^{2}$} \\
\hline & \multicolumn{4}{|c|}{ Average $742 \mathrm{DD}$} & \multicolumn{3}{|c|}{ Average $833 \mathrm{DD}$} \\
\hline & \multirow[t]{2}{*}{ Estimated proportion } & \multicolumn{3}{|c|}{ 95\% Confidence limits } & \multirow[t]{2}{*}{ Estimated proportion } & \multicolumn{2}{|c|}{ 95\% Confidence limits } \\
\hline & & LL & UL & & & LL & $\mathrm{UL}^{2}$ \\
\hline Pinot noir & 0.2362 & 0.1230 & 0.3786 & a & 0.2194 & 0.1171 & 0.3733 \\
\hline Tannat & 0.1676 & 0.0747 & 0.3343 & a & 0.1587 & 0.0684 & 0.3263 \\
\hline Gewürztraminer & 0.2395 & 0.1303 & 0.3985 & a & 0.2308 & 0.1228 & 0.3914 \\
\hline C. Sauvignon & 0.3247 & 0.1843 & 0.5057 & a & 0.3166 & 0.1765 & 0.5003 \\
\hline All cultivars & 0.2475 & 0.1840 & 0.3242 & & 0.2383 & 0.1751 & 0.3154 \\
\hline \multirow{4}{*}{ Joint model } & \multicolumn{3}{|c|}{ LTT $13^{\circ} \mathrm{C}$} & & \multicolumn{3}{|c|}{ LTT $12.26^{\circ} \mathrm{C}$} \\
\hline & \multicolumn{3}{|c|}{ End of the first generation $500 \mathrm{DD}$} & & \multicolumn{3}{|c|}{ End of the first generation 570 DD } \\
\hline & \multirow[t]{2}{*}{ Estimated proportion } & \multicolumn{2}{|c|}{ 95\% Confidence limits } & & \multirow[t]{2}{*}{ Estimated proportion } & \multicolumn{2}{|c|}{ 95\% Confidence limits } \\
\hline & & LL & UL & & & LL & UL \\
\hline All cultivars & 0.0597 & 0.0321 & 0.1082 & & 0.0545 & 0.0286 & 0.1015 \\
\hline
\end{tabular}

${ }^{1} \mathrm{LTT}$ lower-temperature thresholds determined by Avidov and Gothilf (1960), ${ }^{2} \mathrm{LTT}$ lower-temperature thresholds determined by Ringenberg et al. (2005), LL, confidence lower limit, UL, confidence upper limit.

t: Same letter indicates non-significant differences among means $(p \leq 0.05)$

\section{Monitoring larvae}

The first larvae on clusters of grapes were found in midJanuary, and damage began to be significant at the end of February. No damage was observed on Pinot noir because it is harvested in late January or early February. However, the larvae were abundant from late February in clusters remaining on the plants after harvest. On Tannat, the damage was slight, with $4-10 \%$ of clusters infested, depending on the year, but $50-83 \%$ of Gewürztraminer clusters were affected at harvest time (Table 4).

In Progreso, damage on Cabernet Sauvignon and number of male moths caught were very low throughout the season, although this cultivar is harvested on mid-March (Table 4).

The average number of larvae per infested cluster was two on Tannat, five on Cabernet Sauvignon, and four on Gewürztraminer. Larvae were more abundant close to harvest, however at that time, a single larva was enough to degrade the cluster quality, due to colonization of fungi that cause rot. The maximum number of larvae found on a cluster was 85, on 5 March 2005 on Gewürztraminer. In no case did parasitoids emerge from larvae or pupae collected in the field and reared individually in the laboratory.

Larvae and pupae overwinter under the rhytidome or in clusters and dry leaves that persist on the plant and develop slowly due to cold temperatures. Some adults emerged sporadically inside the cloth bags, but most did so when the traps registered the first catch.

\section{Phenological model}

The logistic models, estimated as $\operatorname{logit}(\hat{p})=a+b \cdot D D$ related the proportion of cumulative male moths caught in pheromone traps $(p)$ for each grapevine cultivar to the accumulated DD in each year using the lower-threshold temperature proposed by Avidov and Gothilf (1960) and by Ringenberg et al. (2005). Table 5 presents the estimates of the $a$ and $b$ parameters for the models and the confidence intervals for the population growth rate $(b)$. The corresponding graphs are in Figure 2.

The proportion of cumulative catches and DD were significantly correlated, regardless of the temperature threshold used. Adjusted models for each grapevine cultivar did not differ statistically from each other, both when comparing the growth rate of the logistic model (parameter $b$, Table 5) and when comparing the estimated proportion of accumulated catches at the average DD values (Table 6). For this reason we decided to use a joint model for all four grapevine cultivars and all 4 years of the study (Table 5).

Based on the adjusted models, we estimated the proportion of catches that would be achieved at the end of the first generation, which does not cause economic damage, and we were able to predict their magnitude at harvest for each cultivar (Figures 3). According to the models, the first generation ended at 500 or $570 \mathrm{DD}$, when the proportion of captured adults was 0.06 and 0.05 respectively (Table 6). In our study, the cumulative catches at that time were 326 males in Juanicó and 80 in Progreso in 2005. Depending on the year, the harvests of Tannat, Gewürztraminer, and Cabernet Sauvignon took place between 5 to 20-March, the cumulative DD at this time were $830-960\left(\mathrm{~Tb}=13^{\circ} \mathrm{C}\right)$ and $900-1030\left(\mathrm{~Tb}=12.26^{\circ} \mathrm{C}\right)$.

\section{Discussion}

C. gnidiella presents three generations in southern Uruguay, the same as Ringerberg et al. (2005) estimated for southern Brazil, while Bagnoli and Lucchi (2001) and Coscolla-Ramon (2004) mentioned three to four 

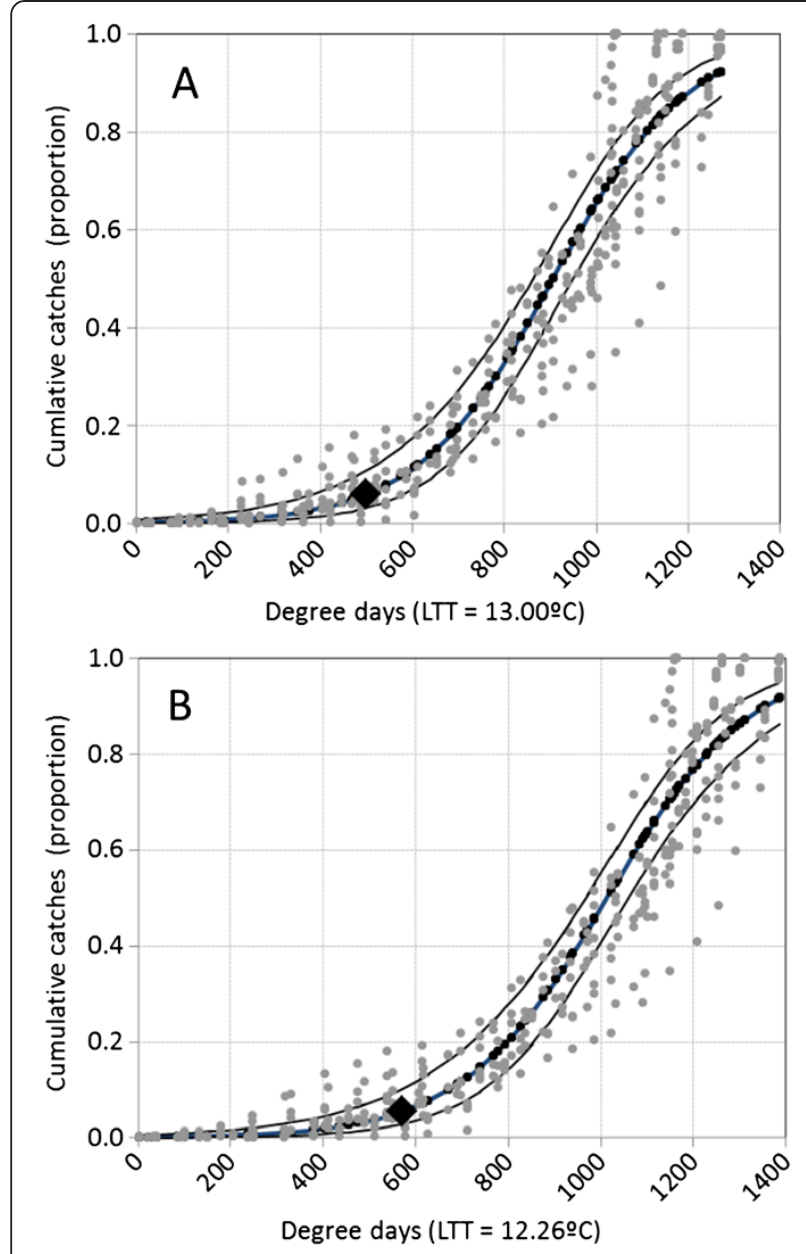

Figure 3 Relationship between degree-days and the cumulative proportion of adult males of Cryptoblabes gnidiella caught in pheromone traps on four grapevine cultivars between $1^{\text {st }}$ December and $31^{\text {st }}$ May in 4 years and at two sites in Uruguay. A) Employs the lower-temperature threshold determined by Avidov and Gothilf (1960); B) uses the lower-temperature threshold estimated by Ringenberg et al. (2005). Observed values are grey, estimated values are black, lines are $95 \%$ confidence limits, and is the estimated proportion at the end of the first generation.

generations in the wine regions of Tuscany, Italy, and Cadiz, Spain, respectively. The first generation does not cause economic damage because the berries are green. However, the second generation is responsible for the majority of the damage because it coincides with berry ripening.

Pinot noir escapes economic damage even in years when the number of male moths caught was very high because it is harvested early. Similar results were observed on this cultivar by Bisotto-de-Oliveira et al. (2007) in Bento Gonçalves, Brazil. On Tannat, the damage is slight, depending on the year, but Gewürztraminer clusters are seriously affected at harvest time. The cultivar Gewürztraminer is over-ripened to obtain a higher- quality wine. Even in the years when Tannat and Gewürztraminer had similar male moths caught and harvest dates, damage was much higher in the latter, suggesting the insect prefers this cultivar. Plant volatiles and/or grape fermentation may act as chemical signals to the pests indicating places suitable for copulation and oviposition (Bisotto-de-Oliveira et al. 2007). In Progreso, Cabernet Sauvignon damage and catches were very low throughout the season, although this cultivar is harvested as late as Gewürztraminer. We concluded that, there was no direct relationship between male cumulative capture from December to harvest time and damage, nor was there a relationship with the maturity date of the late cultivars. Moth detection in pheromone traps enables early prediction of the start of larval feeding on clusters, but the intensity of damage is more closely related to cultivar than with adult catches.

Our results show that $C$. gnidiella does not have a winter diapause in southern Uruguay and does not require an alternate winter host; it can complete its entire life cycle in the vineyard. Ben-Shaul et al. (1991-1992) found similar results when they studied the overwintering of this species in avocado in Israel; larvae remained all winter in dried fruits. The low abundance of flights from the overwintering generation was probably related to the larvae mortality caused by low temperature during the winter months. Depending on the year, average temperatures were below $12^{\circ} \mathrm{C}$ on $52-$ $60 \%$ of winter days. In the 2005-2006 season, spring and early summer had very low populations, despite high male moths caught at the end of the previous autumn. This resulted from a tornado that struck the area in August 2005 and killed larvae and pupae, which was confirmed by observing the remains of clusters inside the cloth bags.

According to our results, the natural parasitism does not appear as an effective measure to reduce populations. Bagnoli and Lucchi (2001), in a review of the current status of biological control in this species, reported small numbers of parasitoids in different areas of the world where the pest is widespread, although Bisotto-de-Oliveira et al. (2007) identified five species of parasitoid associated with C. gnidiella in Brazil.

Based on phenological models and population monitoring, although we use two temperatures as lowerthreshold and two thermal constants, we identify three generations in both cases. Avidov and Gothilf (1960) determined the development thresholds and thermal constants from larvae fed on grapes, while Ringenberg et al. (2005) estimated those parameters from larvae fed an artificial diet, which could explain the different values. Nevertheless, both sets of values were suitable to estimate the onset and duration of $C$. gnidiella generations in Uruguay. The completion of the first generation was 
estimated with a maximum error of 2 or 3 days and the second with an error of 6 or 7 days, depending on year, regardless of the development thresholds used. Overlapping stages of development at the end of the season would explain the greater error in the second generation. The DD model could provide adequate forecasts and facilitate monitoring of insect activity in the field. Therefore, one can calculate how the pest population will develop until the harvest and take the necessary measures to prevent damage to the grapevines.

The predictive capacity of models is especially interesting when simulating population dynamics (Holt and Cheke 1997) and our models should contribute to determining the best times to implement different pest control strategies targeted at the first generation of $C$. gnidiella to prevent damage before harvest. The efficacy of pesticides is related to the percentage of emergent adults and to egg hatch, particularly in species with hidden larval stages (Butcher and Haynes 1960). Conventional control of this pest in its larval stage has not been very efficacious (Bisotto-de-Oliveira et al. 2007). This model could be very useful to improve the efficacy of insect-growth-regulator pesticides, which require precisely timed applications (Ascher et al. 1983), and facilitate the application of insecticides at the egg stage. However, additional data will be needed to validate the model. Analysis by cultivar, despite having no repetitions in space, allowed to verify that population growth was not affected by the specific characteristics of one cultivar. Therefore, we could analyse the pool of information to get a single model where "the cultivar" became a repetition in space. This is the first contribution of a widest line of research planned to study the spatial distribution of C. gnidiella in the whole area of viticulture production in Uruguay.

\section{Competing interests}

The authors declare that they have no competing interests.

\section{Authors' contributions}

Proposed the topic, conceived and designed the study: IBS CMB JF. Carried out the experimental study (field and laboratory work), collected and tabulated the data for the statistical analysis: MVV MVM MVC FD. Analyzed the data and helped in their interpretation: JF. Wrote the manuscript and collaborated with the corresponding author in the revised version of the manuscript: IBS MVV MVC CMB. All authors read and approved the final manuscript.

\section{Acknowledgments}

We express our thanks to the Comisión Sectorial de Investigación Científica (CSIC) of the Universidad de la República and to the Instituto Nacional de Vitivinicultura (INAVI) for their financial support of this project. Special thanks go to the Juanicó and Pisano establishments for allowing and helping with this research in their vineyards.

\section{Author details}

'Department of Plant Protection, Faculty of Agronomy, University of the Republic, Ave. E. Garzón 780, Montevideo 12900, Uruguay. ${ }^{2}$ Department of
Biometry, Statistics and Computation, Faculty of Agronomy, University of the Republic, Ave. E. Garzón 780, Montevideo 12900, Uruguay.

Received: 29 May 2013 Accepted: 6 June 2013

Published: 10 June 2013

\section{References}

Anshelevich L, Kehat M, Dunkelblum E, Greenberg S (1993) Sex pheromone traps for monitoring the honeydew moth, Cryptoblabes gnidiella: effect of pheromone components, pheromone dose, field aging of dispenser, and type of trap on male catches. Phytoparasitica 21:189-198

Ascher KRS, Eliyahu M, Gurevitz E, Renneh S (1983) Rearing the honeydew moth, Cryptoblabes gnidiella, and the effect of diflubenzuron on its eggs. Phytoparasitica 11:195-198

Avidov Z, Gothilf S (1960) Observations on the honeydew moth (Cryptoblabes gnidella Milliere) in Israel: biology, phenology and economic importance. Ktavim 10(3-4):109-124

Bagnoli B, Lucchi A (2001) Bionomics of Cryptoblabes gnidiella (Millière) (Pyralidae Phycitinae) in Tuscan vineyards. IOBCwprs Bulletin 24:79-83

Baskerville GL, Emin P (1969) Rapid estimation of heat accumulation from maximum and minimum temperatures. Ecol 50:515-517

Ben-Shaul Y, Wysoki M, Rosen D (1991-1992) Phenology of the honeydew moth, Cryptoblabes gnidiella (Milliere) (Lepidoptera: Pyralidae), on avocado in Israel. Israel J Entomol 25-26:149-160

Bentancourt C, Scatoni I (1999) Guía de insectos y ácaros de importancia agrícola y forestal en el Uruguay. Facultad de Agronomía - PREDEG/GTZ, Montevideo, p 435

IBentancourt C, Scatoni I (2006) Lepidópteros de importancia económica, reconocimiento, biología y daños de las plagas agrícolas y forestales. Hemisferio Sur-Facultad de Agronomía, Montevideo, p 437

Bisotto-de-Oliveira R, Redaelli LR, Sant'Ana J, Cover C, Botton M (2007) Ocorrencia de Cryptoblabes gnidiella (Millière) (Lepidoptera: Pyralidae) relacionada à fenologia da videira en Bento Gonçalves. Neotrop Entomol 36:555-559

Bjostad LB, Gurevitz E, Gothilf S, Roelofs WL (1981) Sex attractant for the honeydew moth, Cryptoblabes gnidiella. Phytoparasitica 9:95-99

Butcher JW, Haynes DL (1960) Influence of timing and insect biology on the effectiveness of insecticides applied for control of European pine shoot moth, Rhyacionia buoliana. J Econ Entomol 53:349-354

Coscolla-Ramon R (2004) Polillas del racimo (Cryptoblabes gnidella Mill.), p. 44. In: Arias Giralda A, Cabezuelo Pérez P, Coscolla Ramon R, Morales Suarez G, Pérez Martin JL, Toledo Paños J (eds) Los parásitos de la vid: estrategias de protección razonada, 5 th edn. Mundi-prensa, Madrid, p 304

Del Tio R, Martinez JL, Ocete R, Ocete ME (2001) Study of the relationship between sex pheromone trap catches of Lobesia botrana (Den. \& Schiff.) (Lep., Tortricidae) and the accumulation of degree-days in Sherry vineyards (SW of Spain). J Appl Entomol 125:9-14

Holt J, Cheke RA (1997) Modelling, pp 351-378. In: Dent DR, Walton MP (eds) Methods in ecological and agricultural entomology. CAB International, Wallingford, p 387

Ioriatti C, Lucchi A, Varela L (2012) Grape berny moths in western European vineyards and the recent movement into the new world, pp 339-359. In: Bostanian NJ, Vincent C, Isaacs R (eds) Arthropod Management in Vineyards : pest, approaches, and future directions. Springer, London, p 505

Knight AL, Croft BA (1991) Modelling and prediction technology, pp 301-312. In: Van der Geest LPS, Evenhuis HH (eds) Tortricid pests v 5. Elsevier, Amsterdam, p 808

McCullagh P, Nelder JA (1999) Generalized linear models, 2nd edn. Chapman and Hall, London, p 511

MGAP-DIEA (2011) Anuario estadístico agropecuario., (On line). Accessed: June 2012. Available: http://www.mgap.gub.uy/Dieaanterior/Anuario2011/ DIEA-Anuario-2011-web.pdf

Milonas PG, Savopoulou-Soultani M, Stavridis DG (2001) Day-degree models for predicting the generation time and flight activity of local populations of Lobesia botrana (Den. \& Schiff.) (Lep., Tortricidae) in Greece. J Appl Entomol 125:515-518

Riedl H, Croft BA, Howitt AJ (1976) Forecasting codling moth phenology based on pheromone trap catches and physiological time models. Can Entomol 108:449-460 
Ringenberg R, Botton M, Silveira M, Nondillo A (2005) Biologia comparada e exigências térmicas de Cryptoblabes gnidiella em dieta artificial. Pesq Agropec Bras 40:1059-1065

SAS Institute Inc (2009) SAS/STAT 9.2 User's Guide. SAS Publishing, Cary, North Carolina, p 584

Scatoni I, Bentancourt C (1983) Cryptoblabes gnidiella (Millière), una nueva lagarta de los racimos en los viñedos de nuestro país. Rev A I A (Uruguay) 1:266-268

doi:10.1186/2193-1801-2-258

Cite this article as: Vidart et al:: Relationship between male moths of Cryptoblabes gnidiella (Millière) (Lepidoptera: Pyralidae) caught in sex pheromone traps and cumulative degree-days in vineyards in southern Uruguay. SpringerPlus 2013 2:258.

\section{Submit your manuscript to a SpringerOpen ${ }^{\circ}$ journal and benefit from:}

- Convenient online submission

- Rigorous peer review

- Immediate publication on acceptance

- Open access: articles freely available online

- High visibility within the field

- Retaining the copyright to your article 